Article

\title{
Global Multi-Protagonist Trends in a Local Setting: The Case of Frozen Land and Autumn Ball
}




\section{ABSTRACT}

This article explores whether a specifically regional quality can be identified in the following Finnish and Estonian multi-protagonist/network narrative films: Aku Louhimies' Frozen Land (Paha maa, Finland, 2005) and Veiko Öunpuu's Autumn Ball (Sügisball, Estonia, 2007). The article begins by providing an overview of the discussion regarding multi-protagonist films - a film form in which several lead characters are commonly connected via accidental encounters. Thereafter, an examination is made of how the form's widely recognised generic qualities are represented in the Northern and Eastern European examples. As an overview of the discourse illustrates, multi-protagonist film is mainly interested in urban spatiality, contingency and human interconnectedness. It is also shown that these examples from the cinemas of small nations follow global trends rather closely. At the same time, Frozen Land and Autumn Ball can be seen as representing a specifically regional sensibility that is not only interesting in its own right, but which can also be understood as directly influencing the character-action.

\section{FOREWORD}

Both Aku Louhimies' Frozen Land (Paha maa, Finland, 2005) and Veiko Õunpuu's (Sügisball, Estonia, 2007) offer a deeply unflattering representation of Finland and Estonia (respectively) - an image that drastically differs from the innovative and 'one with nature' image that the countries themselves put forth.' The capital cities, Helsinki and Tallinn, where most of the films' action takes place, are depicted as drab and almost uninhabitable environments. Because of the highly unfriendly take on the life in these countries, the films appear to present themselves as typical examples of what Nikolaj Lübecker terms 'feel-bad

See, for example, http://www.visitfinland.com/ and https://www.visitestonia.com/en. films' (Lübecker 2015: 2), i.e. films that both thematically and formally aim to disorient and depress the audience. Just like Carol (Julianne Moore) from Safe (Todd Haynes, UK/USA, 1995), which is a prime example of the feel-bad form for Lübecker, the characters in Frozen Land and Autumn Ball behave as if haunted by an unidentifiable disease that is draining their will to go on living. However, unlike the isolated occurrence of Carol's illness, the multi-protagonist format of Frozen Land and Autumn Ball universalises this quality as a common feature of all the Finno-Ugric characters. Below, I will explore to what extent the films' utilisation of the widely recognised generic devices of multi-protagonist film can be understood to evoke the specifically regional notion of kaamos - a word of Northern Sami origin 
(also a Finno-Ugric language) that is spelled the same in both languages, and that connotes not only the polar night but also the far-reaching anguish emerging from the cold and darkness.

Tracing the connections between Frozen Land and Autumn Ball a bit further and continuing the comparisons with Safe, we see that a clear difference exists between the films. While Carol is in her vulnerable state, her supportive family seeks to isolate her from the rest of society, but the characters in Frozen Land and Autumn Ball are left on their own and turn to alcohol, drugs, random sex, and even murder, in an attempt to find their way out of their emotional deadlock. Perhaps the most definitive difference between Safe on the one hand and Frozen Land and Autumn Ball on the other is that the latter two begin by evoking a much darker atmosphere - one starts off with a funeral and the other with a scene of domestic violence and attempted suicide, very unlike the seeming suburban bliss that surrounds Carol. Lübecker (2015: 2), citing a quote by Aristotle, i.e. 'the end is everything', believes that Safe is a feel-bad film throughout and offers no redemption at the end. On the other hand, the Finnish and Estonian characters return to the same setting as in the beginning to offer some hope at the end. Thus, initially it could be said that while Safe examines an exceptional case where the protagonist's situation keeps deteriorating, the fates of the numerous lead characters in Frozen Land and Autumn Ball suggest that the difficulties they face are not unprecedented, but a usual part of life in those countries - something that people have to learn to cope with if they are to survive.

In addition to the circular multiprotagonist narrative structure of Frozen Land and Autumn Ball, the films share a number of common features; even if it could be argued that Frozen Land targets a more mainstream audience and Autumn Ball has a clear arthouse inclination. ${ }^{2}$ This difference

2 Nonetheless, Autumn Ball was also popular in Estonian cinemas with over 38,000 viewers (see Eesti filmi arengusuunad 2012-2020). already emerges from the fact that many of the characters in Frozen Land are united by something as mundane as a $€ 500$ bill, while some of the characters in Autumn Ball are connected by poetry - a quote by Fernando Pessoa. Although the tactic employed by Autumn Ball proved more successful, with the film becoming the first Estonian film to win the Venice Film Festival's Horizon Prize among other awards, it appears that both films try to take advantage of the general popularity of multi-protagonist film at the time. Mette Hjort highlights the importance of the Academy Awards for the recognition of the cinema of small nations (Hjort 2005: 5). And although neither of these films was nominated for the award it seems significant that the films' release dates paralleled what in retrospect appears to be the peak of fame for multi-protagonist films. At the time such films as Crash (Paul Haggis, USA/ Germany, 2004), Syriana (Stephen Gaghan, USA, 2005) and Babel (Alejandro González Iñárritu, USA/Mexico/France, 2006) were all being recognised at the Oscars.

Another similarity between the two films is that both Frozen Land and Autumn Ball represent countries where a small Finno-Ugric language is dominant. These languages are very closely related, and since they are not Indo-European languages, it is generally believed that Finland and Estonia are culturally more closely related than Estonia is to its other Baltic neighbours of Latvia and Lithuania (the only countries where the Eastern Baltic languages are spoken). However, for various reasons, not the least being the prestige of the affluent Scandinavian countries, Finland would like to associate itself with the latter. Yet, Estonia and Finland, similarly to the other states that had gained independence from Russia in the aftermath of World War I, were once both considered Baltic states (Maude 2010). Interestingly, Frozen Land also seems to point to this somewhat supressed history by modelling itself after Leo Tolstoy's 1912 novella The Forged Coupon (Фальшивый купон, 1912; see Tolstoy 2006) - a story set in tsarist Russia about an evil deed setting off a chain reaction 
through its various characters. It would be useful to provide an overview of the genre's more general features before exploring the films' regional specificity and the issue of the relationship between the environment and the characters.

\section{THE EARLY DEBATE}

Since the 1990s a 'new' form of film narrative has increasingly gained popularity. These films, in which several lead characters and their storylines intersect through happenstance, are usually called either 'multi-protagonist films' (Carmago 2002, Azcona 2010, Melzer et al. 2004, Tröhler 2010, Smith 2005) or "network narrative films' (Bordwell 2006 and 2008, Silvey 2009 and 2012, Beal 2009, Ciafone 2014). ${ }^{3}$ Because the form is well represented internationally, it is deemed by some authors to be a 'global genre' (Silvey 2012), while others have even referred to it as the 'royal genre' (Deleyto 2012: 231) of the present - meaning that the form, with is broad interests (such as globalisation, social interconnection, etc.) and tendency to downplay individual heroes, is seen as being very suitable for representing the contemporary Zeitgeist.

The prominence achieved by multiprotagonist film in the middle of the first decade of the 21 st century builds on the accomplishments of earlier examples, particularly from the 1990s. After the success of films such as Short Cuts (Robert Altman, USA, 1993) and Pulp Fiction (Quentin Tarantino, USA, 1994), critics were quick to praise the 'new' and innovative way of storytelling. Unlike the classical Hollywood narrative that relies mostly on an individual (usually male), goal-oriented protagonist and his/her love interest or sidekick/friend, the exploration in a multi-protagonist film is conducted through an array of lead characters. ${ }^{4}$ However, unlike ensemble films, which most often focus on families and friendships (e.g. Hannah and Her Sisters

3 Terminology regarding the form varies to a much greater extent as I will explain below. However, in the interest of clarity I will use the term 'multi-protagonist film' throughout the article.

4 The main qualities of the classical narrative model are explained in Bordwell et al. 2005: 12.
[Woody Allen, USA, 1986] and The Big Chill [Lawrence Kasdan, USA, 1983]), or unite its characters for a single goal (e.g. The Great Escape [John Sturges, USA, 1963]), multiprotagonist films tends to connect the characters - often only for the viewer - contingently, i.e., the characters usually share no other relationship other than the fact of their meeting. ${ }^{5}$ Evan Smith (1999/2000) provides an excellent illustration of the dominant current of the early criticism although he does not claim that multi-protagonist film challenges the 2,000 year-old legacy of Aristotelian storytelling, he does express noticeable excitement over the 'new template' that is questioning the dominance of the classical Hollywood narrative. ${ }^{6}$ Also since the early 1990s terms such as Altmanesque and Tarantinoesque have come into use - primarily signifying films with several interlinked lead characters - and become part of the related critical literature and even the popular vocabulary?

Another characteristic of the discussion concerning this form has been the large amount of ad hoc terminology that critics and academics alike have used to describe the central qualities of multi-protagonist film. Terms such as 'hyperlink cinema' (Quart 2005), 'alternative plots' (Berg 2006), 'tandem narrative' (Aronson n.d.), ${ }^{8}$ 'modular narrative' (Cameron 2006), 'multiple-draft films' (Branigan 2002), 'database narratives' (Manovich 1999, Kinder 2002), 'puzzle films' (Buckland 2009) and 'complex narrative films' (Simons 2008) have all been used to discuss multi-protagonist films. Yet, these terms often define a larger

$5 \quad$ Nonetheless, drawing a clear dividing line between the two forms is not a simple task, see Azcona 2010: 20.

6 The fact that the article considers the increasing emergence of multi-protagonist film to be a significant change in the traditional Hollywood story model is already indicated by the subtitle, 'Rewriting the Hollywood Formula' (Smith 1999/2000: 88).

$7 \quad$ This being largely the case even when considering the fact that Robert Altman's earlier multi-protagonist examples, such as Nashville (USA, 1975), the artistic merit of which some have argued exceeds his later work (Rich 2009), were released almost twenty years prior to Short Cuts.

8 Although Linda Aronson also uses the term 'the multiple protagonist narrative', she describes it as a more traditional ensemble film, while preserving the term 'tandem narrative' for multi-protagonist film as it is understood in this article (see Aronson n.d.). 
group of qualities than simply 'a multiplicity of characters of similar narrative relevance', which is how Maria del Mar Azcona (2010: 2) defines multi-protagonist film. In other words, these terms also tend to include examples that cannot be classified as multi-protagonist films. Evan Smith's (1999/2000: 95) usage of the term 'thread structure' - focusing mainly on the different narrative lines, rather than the number of lead characters - is an example of how difficult it is to describe the precise quality that separates this seemingly new type of film from the rest of cinema. Concentrating on the number of storylines leads Smith (1999/2000) to discuss The English Patient (Anthony Minghella, UK/USA, 1996) alongside Pulp Fiction, although it could be argued that the former, a love story told via flashbacks, has much more in common with classical narrative cinema than the latter. ${ }^{9}$

\section{THE NEW IS THE FORGOTTEN OLD}

Thanks to the fact that authors such as David Bordwell (2006 and 2008), Margrit Tröhler (2007 and 2010) and Maria del Mar Azcona (2005, 2008 and 2010) wrote extensively about multi-protagonist film a certain consolidation of the terminology occurred. Although articles that introduce new terms to describe the form are still being published today, Bordwell's 'network narrative film' and Tröhler and Azcona's 'multi-protagonist film' have become the main terms that have been used repeatedly since their introduction. ${ }^{10}$ Among others, these authors also began to stress the global reach of

The multiple storyline approach is still a minor trend considering the fact that a recent book (Parshall 2012) also focuses on this aspect. It has also led the author to include single-protagonist examples that have multiple storylines, such as Run Lola Run (Lola rennt, Tom Tykwer, Germany, 1998).

10 'Puzzle film' is also a widely used term, but it is rarely used to discuss films with a large number of lead characters, although in the introduction to Puzzle Films: Complex Storytelling in Contemporary Cinema Warren Buckland (2009:11) does mention examples of multiprotagonist film, such as Amores perros (Iñárritu, Mexico, 2000) and 21 Grams (Iñárritu, USA, 2003). Cloud Atlas (Lana Wachowski et al., Germany/USA, 2012) would be another more recent example of a film that could fit both criteria. multi-protagonist film and highlighted the form's long history (Tröhler 2010, Azcona 2010: 9-25). Bordwell succinctly illustrates the extended history of multi-protagonist film, as well as the form's surprising constancy, when he states that most of the form's central traits were present already in some of its earliest examples. According to Bordwell, it was Grand Hotel (Edmund Goulding, USA, 1932) that 'laid down some basic conventions [of multi-protagonist film]: in one locale, a star-packed cast portrays characters linked by contingency' (Bordwell 2006: 94). Leaving the spatial restriction and the preference for contingency aside for a moment, it is evident that the third feature of Bordwell's claim - a star-packed cast - is highly dependent on the context. While Grand Hotel features such internationally recognised cinema icons as Greta Garbo, Joan Crawford, John Barrymore and Lionel Barrymore, in the context of North/Eastern European cinema no performer wields similar star power.

Yet, the question of stardom as it relates to multi-protagonist film has received relatively little attention. It is not within the scope of this article to try and fill this gap in scholarly knowledge, but the importance of the topic should be noted, especially in regard to the cinema of small nations. The issue needs further scrutiny, because as the criticism concerning the two examples discussed here indicates, the characters and actors from less well-known cinemas are constantly mistaken for one another.11 This suggests that the central tension of the form, i.e. between its interest in contingency and the artifice emerging from the repeatedly criss-crossing lead characters, does not manifest itself in the same way in the cinema of small nations as it does in films featuring famous superstars.

As several authors have noted, the profound interest of multi-protagonist film in accidentality and contingency - represented by the randomly criss-crossing lead

11 For instance, regarding Autumn Ball one critic (Lanthier 2009) mixes up Mati (Rain Tolk) with Laura's ex-husband (Ivo Uukkivi), thus merging the different characters' storylines. 
characters - is an uneasy fit with the form's own rigid structure, where almost nothing is left to chance. Allan Cameron calls this tension between form and content 'a fraught relationship between contingency and narrative order' (Cameron 2006: 65). Vivian Silvey identifies the central question of multi-protagonist film as "how to relay the postmodern promise of endless complexity, without subordinating difference to a simplified reduction of totality' (Silvey 2009: n.p.). Bordwell notes a similar artificiality when he explains that "unlike coincidences in real life, movie coincidences create "small worlds" in which characters will intersect again and again, especially if the duration and locale of the action are well circumscribed' (Bordwell 2006: 98). Although these authors mostly see this problem as a potential weakness of multi-protagonist film that downplays the credibility of the worlds depicted, Azcona finds that the conflict between chance and order is precisely what makes the form 'a template perfectly equipped to deal with a tension of this sort' (Azcona 2010: 55). It is a tension that Azcona, based on Mary Ann Doane's (2002) study on the relationship between contingency in cinema and modernisation, understands is also present in real life - on the one hand, people are fascinated by the unexpected and obscure, on the other, they find comfort in routine and value rationality (Azcona 2010: 55).

\section{IT IS A COLD WORLD (IN THE NORTH)}

Practically all the commentators who have written about Frozen Land have commented on the film's cold emotional tonality (see Dawson 2006, Fundin 2006, Gronvall n.d., Murray 2006, Foster 2010). The film connects eight different characters that could be considered central to the film's narrative web of solitude, betrayal, alcohol and drug abuse, attempted suicide and murder. Since the direct translation of the film's title is 'a bad land', the film, which is set in Helsinki, plays on the dual meaning of bad/frozen as they refer to the barren land and climatic coldness of the setting, and metaphorically to the characters' emotional disdain..$^{12}$ Like in Terrence Malick's film Badlands (USA, 1973) with a similar name that also makes use of the double meaning, the environment in Frozen Land plays such a significant role that it could be argued that it is one of the characters. In the film, it is mostly dirty piles of snow that haunt the characters where ever they go. Badlands, as the title suggests, depicts an aimless journey towards the clay-rich soils of Montana, but Frozen Land, like most multi-protagonist films, focuses primarily on an urban landscape.

Frozen Land begins with an ecstatic and fast-paced club scene, shot in warm tonality, only to have this warmth contrasted in the next scene, which shows a drifter named Niko (Jasper Pääkkönen) emerging from the metro into Helsinki's cold and greyish winter. After this, the film cuts to a quote from Eppu Normaali, one of Finland's most popular rock bands, describing an innocent soul being born into the freezing northern lands. As an additional reference to the local setting, the title of the song containing the quote is called $A$ Land of Mournful Songs (Murheellisten laulujen maa). The film then cuts to a different setting, in this case to a funeral taking place in a barren forest, where Niko - looking in better shape than in the previous scene (as it later turns out, this is the film's ending) - gives a speech about hope for a better future against all the odds. As a sign of the fragility of this dream, the sound of a nearby freight train grows increasingly louder, until it eventually drowns out all the other sounds.

The emotional tenor of Õunpuu's feature length debut Autumn Ball equals that of Frozen Land. In the film, there are six characters that could be considered the 'lead characters', although, as is often the case with multi-protagonist film, the lead character of one scene can be a minor character in another. Autumn Ball also deals with loneliness, alcoholism, adultery and violence (potentially also murder, which

12 Such double play is continued with Louhimies' next film, titled in English Frozen City (Valkoinen kaupunki, Finland, 2006). 
takes place off-screen). The film opens with a quote from Antonio Tabucchi - mistakenly attributed to Fernando Pessoa in the film - 'I was like grass and they didn't pull me up' (Tabucchi 1992: 63). Tabucchi's work of prose that contains the line is indeed about Pessoa; and later in the film, a woman from a literature conference (Katariina Unt, as Katariina Lauk) correctly quotes Pessoa's The Tobacco Shop (Tabacaria, 1933) to a waiter named Theo (Taavi Eelmaa), saying, 'I made of myself what I was no good at making / And what I could have made of myself I didn't' (Pessoa 1998). Theo is secretly impressed by the beauty of these words and later repeats them meaningfully to his casual sex partners, only to be laughed at and having his words countered by an obscene proverb. This is one of the many futile attempts made by the characters to establish more meaningful connections.

The constant emotional rejections add to Theo's frustration and his inability to change his life for the better finally culminates in a violent outburst in which he seriously injures, if not kills, a local cultural dilettante (Raivo E. Tamm). The scene, like the rest of the film, takes place in Lasnamägi, Tallinn's largest Soviet-era residential district. The prefab concrete slabs of the buildings are deliberately shot in unfavourable light with debris laying all around. The film's colour palette is dominated by shades of grey and faded blues. As the scenes focusing on drab sites and bittersweet quotes at the beginning of both films suggest, the northern (in one case also post-Soviet) landscape is not merely a decorative setting for the films, but more like a force of nature that actively works against the hopes and dreams of the films' numerous characters. Nonetheless, in addition to the coldness of the environment, which could be seen as specific to Finland and Estonia, the films suggest regionality by implying that this environment reflects the Finno-Ugric characters' inability to connect with each other. In other words, both films strongly support the stereotypical image of Finno-Ugric people as being especially introverted.
It is apparent from the opening shot that Tallinn's cold and unwelcoming scenery plays a similarly central role in Autumn Ball as Helsinki does in Frozen Land. In the beginning of the film we see a central character, a writer named Mati, desperately holding on to the railing of his apartment's balcony as if he were about to be blown away by the cold autumn wind surrounding him. The scene is accompanied by an ominous musical score (by Ülo Krigul) and lingers on for quite a while, until the viewer can almost feel Mati's physical suffering. ${ }^{13}$ When the film finally does cut from a medium-close up to a long shot, we see Mati dwarfed to almost insignificance amid the endless Plattenbauten, gigantic concrete housing blocks reaching for the sky. The dark sky as seen in the film seems to belong exclusively to the pitch-black seagulls that are flying around aimlessly with no chance of escaping the strong Arctic winds. Mati then goes back into his apartment, having just contemplated suicide as it soon turns out, and begins strangling his ex-girlfriend Jaana (Mirtel Pohla) after she rejects his feeble attempts at intimacy. Just another day in the post-Soviet North, Autumn Ball seems to be saying with its neutral colour palette and distancing cinematography (by Mart Taniel) - the camera is handheld, but kept still most of the time, thereby giving the scenes an uninvolved documentary feeling.

Despite their shared linguistic, cultural and historical roots, Finland and Estonia are two very different countries today. For instance, Finland's nominal GDP per capita is twice that of Estonia's (IMF 2017a and 2017b). However, the films are strikingly similar when it comes to the unflattering way in which they depict the countries and their citizens. Compared to Mati Unt's novel

13 Such expressions of physical suffering appear to be a common feature in Õunpuu's films. In one scene of his The Temptation of St. Tony (Püha Tõnu kiusamine, Estonia/Finland/Sweden, 2009), the lead character Tony (Taavi Eelmaa) runs around naked for an extended period in a freezing Estonian winter, covered only by the national flag. Eva Näripea and Ewa Mazierska associate such explorations of (emotional) coldness in Õunpuu's films to a rejection of neoliberal discourses about intimacy (Näripea, Mazierska 2016). 
of the same title (Unt 1979), Autumn Ball, the film, has moved from Mustamägi to Lasnamägi and ventures to the industrial areas outside Tallinn in order to convey an 'authentic' impression of the post-Soviet cityscape. Therefore, the film actually creates a unique vintage setting that is similar to the world familiar from many of Aki Kaurismäki's films. Frozen Land's strong focus on the less fortunate members of the population brings the film's representation of Finland closer to Autumn Ball's view of Estonia than the reality in either country would lead one to believe. Niko has to forge some money to buy back a stereo from a pawnshop, which his father, a sacked schoolteacher named Pertti (Pertti Sveholm), had pawned to buy alcohol. The forged bill is then obtained by Isto (Mikko Kouki), who in turn must pawn his television set to impress his ex-girlfriend, whereas Teuvo (Sulevi Peltola) later has to give up the van in which he lives to cover his expenses. Considering the film's multi-protagonist form, which tends to leave a universalised impression of the state of affairs, and the large number of poverty-stricken characters in Frozen Land, one could say that this is hardly a fair depiction of Finland, a country that is known for having one of the world's most generous social support systems.

\section{DO YOU REMEMBER THE QUESTIONS WE ASKED EACH OTHER AS KIDS?}

The great attention paid to exploring the cityscape, as exemplified by Frozen Land and Autumn Ball, is a very common feature in multi-protagonist films. An interest in spatiality, particularly in a contemporary urban environment, is often expressed in the titles of these films. For example, this is the case with Nashville, Night on Earth (Jim Jarmusch, France/UK/Germany/USA/ Japan, 1991), Les Rendez-vous de Paris (Éric Rohmer, France, 1995), Magnolia (Paul Thomas Anderson, USA, 1999), Paris, je t'aime (Olivier Assayas et al., France/ Liechtenstein/Switzerland/Germany, 2006), Babel and New York, I Love You (Fatih Akin et al., USA, 2008). The most popular locations are Los Angeles (Short Cuts, Twenty Bucks [Keva Rosenfeld, USA, 1993], Pulp Fiction, 2 Days in the Valley [John Herzfeld, USA, 1996], Magnolia, Things You Can Tell Just by Looking at Her [Rodrigo García, USA, 2000], Crash and Valentine's Day [Garry Marshall, USA, 2010]) and New York (Do the Right Thing [Spike Lee, USA, 1989], Crimes and Misdemeanors [Woody Allen, USA, 1989], Smoke [Wayne Wang, Paul Auster, USA, 1995], Everyone Says I Love You [Woody Allen, USA, 1996], Thirteen Conversations About One Thing [Jill Sprecher, USA, 2001] and New Year's Eve [Garry Marshall, USA, 2011]).

There are thematic and formal benefits related to choosing a city as a location for multi-protagonist films. A central one is that the contingency and interconnectedness that characterises multi-protagonist film would seem even more artificial than already noted by academics, if the accidental encounters between the main characters occurred in less populated areas than in metropolises. How often does anyone meet a stranger who has a significant effect on his/her life in a forest or a field? But it is easy to arrange such encounters in city settings, for example, via a traffic accident - the latter being a highly common trope in multi-protagonist films, used also by both Frozen Land and Autumn Ball. In short, a cityscape allows multi-protagonist film to approach 'the big issues' it is mostly interested in - i.e. how people's lives affect those around them. These are the questions we used to ask when we were kids, as Niko says at both the beginning and end of Frozen Land. However, a regional quality can also be noted in regard to the central problem of multi-protagonist film, i.e. its interest in contingency and its rigid structure. While Celestino Deleyto has recently demonstrated how even multi-protagonist films are unable to fully capture the complexity of megacities such as Los Angeles (Deleyto 2016), some of the accidental connections that multi-protagonist films typically utilise to depict social complexity seem more probable in a city the size of Tallinn with 
less than half a million citizens than in Los Angeles or New York. For instance, there is very little artifice involved in the scene from Autumn Ball where Mati receives a parking ticket from somebody that he knows personally. While not everybody knows each other in Tallinn, such occurrences are nonetheless much more probable in small cities than in large metropolises.

Although Frozen Land and Autumn Ball choose cityscapes for the same reasons as their global counterparts - in order to explore socio-philosophical concerns via random encounters between strangers for the local audience the environments in these films have specific regional connotations. I do not mean the obvious ones, i.e. that most local viewers will recognise the shooting locations, but rather that the cold and dark northern environments are recognised as having a significant impact on the characters' motivations. Because regionality is strongly emphasised in both films, the setting has also been noted by several international critics. For instance, commentators called Frozen Land an "epic wallow in Finnish despair' (Murray 2006) and 'an over-extended slice of Scandinavian miserabilism' (Dawson 2006). In Autumn Ball, critics (Rizov 2009, Anonymous 2009) noticed the way the film openly questions the Baltic consciousness by having the woman from the literature conference that Theo meets ridicule the idea of a Baltic consciousness as an artificial construct. Vadim Rizov claims that, although the film explicitly denies such a unifying idea, the "miserable people moping around horrendous apartment towers of the finest Soviet vintage, chain-smoking and drinking their way through despair' are in fact a perfect representation of the Baltic consciousness (Rizov 2009). Having put forth such a provocative idea, it is unfortunate that the author does not develop it any further.

Noel Megahey also draws attention to both regionality and the form's sociophilosophical interests when he claims that Frozen Land successfully expands the source material from Leo Tolstoy's novella The Forged Coupon and Robert Bresson's
L'argent (France/Switzerland, 1983) into a local context 'to say something about the present-day circumstances of people in Finland' (Megahey 2007). As both Tolstoy's novella and Bresson's film are interested in accidental connections, it remains unclear how this contingent interconnectedness is specific to Finland. It is interesting to note that Megahey uses both the terms 'chaos theory' and 'butterfly effect' to explain the connectedness of strangers in Frozen Land. Similar vocabulary is commonly used by both critics and filmmakers to describe multi-protagonist films. ${ }^{14}$ Azcona has argued that one of the main reasons why multi-protagonist film can be considered to be a fully developed genre is the very constant nature of the terminology that is being used to describe examples of the form (Azcona 2010: 1). It appears that Frozen Land and Autumn Ball are following generic qualities of multi-protagonist film closely enough to be easily recognised as such by the critics. ${ }^{15}$

In the case of Frozen Land it should be noted that the film is very self-aware of its interests. Via Pertti, a literature teacher, the film makes a direct reference not only to Tolstoy, but also to the principle that one character's actions have a direct consequence on another's. Later in the film Antti, a physics teacher (Petteri Summanen), who in a way assumes Pertti's position when the school fires the literature teacher to hire a physics teacher, explains the chaos theory to his class. Although Antti explains this idea as it is understood in physics, the film suggests that this inclination towards disorder also applies to life more generally - during the lecture Antti finds out that his wife, a police officer named Hannele (Matleena Kuusniemi), has died in the line of duty. Some commentators have seen this self-reflexivity as 'unfortunate' and said that

14 See, for instance, Lorraine Ali's interview with Iñárritu where he talks about his earlier multi-protagonist trilogy, consisting of Amores perros, 21 Grams and Babel (Ali 2015).

15 For instance, the term 'Altmanesque' is used by a critic (Lanthier 2009) to describe Autumn Ball and Pulp Fiction is mentioned in a review (Foster 2010) of Frozen Land. 
the director "has a tendency to spell out to the audience the film's ideas' (Dawson 2006), without really elaborating why self-reflexivity should be considered a shortcoming of the film. The tendency of openly exemplifying the film's structural logic is a very common feature in multi-protagonist film..$^{16}$ One example of this similarity is a scene in Thirteen Conversations About One Thing when a physics professor (John Turturro) is giving a lesson about almost constant deceleration/ acceleration by bringing up the examples of a braking car and a falling body. This lesson directly precedes a car accident caused by another lead character (Matthew McConaughey), and later in the film, one of the students in the class (Rob McElhenney) dies by jumping off a building. ${ }^{17}$

\section{DATED EXISTENTIALISM OR A QUESTION OF VERISIMILITUDE?}

Although critics have no trouble recognising the global multi-protagonist trends in Frozen Land and Autumn Ball, they appear somewhat perplexed about how to interpret the films' excessive pessimism and seemingly dated explorations of existentialistic angst. One author, when writing about Autumn Ball, openly expresses this difficulty by saying: 'Americans with limited knowledge of Baltic culture will spend the duration [of the film] puzzling over what additional dimension their ignorance might be shrouding' (Lanthier 2009). Thus, while both regionality and the cold emotional tonality, or the 'epic wallow' as one commentator puts it (Murray 2006), are regularly noted, the two are largely treated sideby-side, without being connected. However, based on even the few scenes that I have described, a couple of constant features can be highlighted: an emphasis on the

Tröhler has made a similar argument regarding, among other elements, the 'reflexiveness of actor performance' that creates a tension with "the chronicle-like presentation of a fictional everyday world' (Tröhler 2010: 470).

17 Additionally, the professor in Thirteen Conversations goes on to explain entropy by bringing an example of two gases mixing that cannot themselves unmix or 'go back' to the way they were, the latter being one of the central ideas of the film that is regularly brought up by different characters. cold environment and a contrast between overwhelming happiness and utter (self-) destructiveness.

Because most of the key scenes in both of the films occur entirely outdoors or when moving from indoors to outdoors or vice versa and a number of night scenes are depicted, the dark northern landscape could be seen as having a direct influence on the characters' actions. For instance, Theo drags the drunken cultural dilettante out of the restaurant where he works before he starts attacking him. The isolated landscape offers him a perfect backdrop for violently attacking a person during broad daylight. However, it appears that the landscape around the men - a dirty field of broken glass and concrete - truly represents their pitiful states. Just recently, the married director had attempted to initiate an affair with a single mother named Laura (Maarja Jakobson) and Theo has been repeatedly unsuccessful in forming more lasting relationships with women, despite his sexual allure. Before Theo's attack, the viewer had seen him falling in love with Ulvi (Tiina Tauraite), the wife of another central character, only to be rejected with the remark that he has mistaken adultery for love. This serves as yet another contrast between extreme happiness and utter despair, similar to the one suggested at the beginning of Frozen Land, where an ecstatic club scene is contrasted with Niko freezing in greyish Helsinki. Just like Autumn Ball, Frozen Land repeats these sharp emotional contrasts throughout the film. Most pronouncedly in a scene in which Isto and Teuvo's drunken frenzy - involving masturbation, vandalism, reckless driving on a snowfield in a pitch-black Finnish night, and random sex - ends suddenly with the sexually frustrated Teuvo killing both Isto and his partner (Eija Koskimaa) and then attempting to take his own life.

The warm-toned club scene at the beginning of Frozen Land is replayed in full later in the film, right after Niko's handsome and successful best friend Tuomas (Mikko Leppilampi) is arrested because Niko, who was supposed to act as the 
getaway driver, left him behind during a heist. In the club, Niko takes advantage of Tuomas' fiancé Elina (Pamela Tola), whom he has secretly been desiring, and uses her vulnerable emotional state by offering her drugs in order to sleep with her. Thus, the greyish winter at the beginning of Frozen Land could be seen as representing Niko's emotional reality, much like Lasnamägi echoes Theo's feelings, while the club scene represents Niko's temporary excitement over being part of Tuomas' world. But, similarly to Autumn Ball, the landscape not only represents Niko's state, but to an extent guides his actions. After Niko's father Pertti kicks him out, the freezing Finnish winter is one of the reasons why Niko seeks out Tuomas in the first place - he has nowhere to stay, and the cold streets of Helsinki are not ideal for wandering outside (Isto and Teuvo randomly meet largely for the same reason). During the heist it is the endless masses of dirty snow we see surrounding Niko, along with the car that won't start, that make him nervous and cause him to leave Tuomas behind. The scene begins with a shot of the getaway car parked between piles of snow, and later, when Niko flees prematurely, he can be seen as constantly falling because of the deep snow and slippery icy fields around him. When Tuomas exits the building from which he had stolen some digital data and looks for the getaway car, he is also greeted by masses of snow that he has to cross in order to escape. Tuomas' nightmarish situation creates a sharp contrast with the prior scenes where Tuomas had proposed and made love to Elina (who, as we later learn, had become pregnant from this intercourse).

Highlighting the centrality of the northern post-Soviet environment in the lives of the Autumn Ball characters, Mati is seen thinking on his drab balcony before he enters his apartment and starts strangling Jaana. Once Mati manages to force Jaana to the ground, he starts choking and groping her. However, after realising the futility of his actions, he turns the violence against himself - demonstratively consuming a handful of pills and washing them down with alcohol.
After representing the collapse of one's world Autumn Ball cuts to its title, displayed over a frozen pool of dirt amid Lasnamägi's endless apartment buildings. A sharp contrast with the dull scenery is created by a sweet folklore lullaby (interpretation by Veljo Tormis) that can be heard over the scene. The audio cue is followed by scenes of Jaana and Mati shot in soft lighting to indicate an earlier and much happier time in their relationship. Alluding to the scene's postSoviet setting, the characters find humour in reading Talking Openly about Marriage (Avameelselt abielust [Paloheimo et al. 1974]), an outdated account of sexuality that was ground-breaking for its 'openness' during the early 1970s in the Soviet Union. This reference to Estonia's recent social transformation is echoed by the song's lyrics, which ask where all the innocent girls are going as the night falls. The contrast between Mati and Jaana's past and present - along with the song, titled How Can I Recognise My Home (Kust tunnen kodu) - suggests the difficulty of finding one's way in the cold and dark borderland.

In Frozen Land, the climate is also a nemesis in the characters' lives. When Pertti is told that he will be fired, atmospheric music (by Samu Heikkilä) drowns out the principal's (Susanna Mikkonen) dialogue, as the camera slowly studies Pertti's facial expressions. As a further reference to the shock suffered by Pertti due to the sacking, the film cuts to an unfocused shot of the principal. The film then shows Pertti struggling to get home by climbing over endless piles of snow. The next scene cuts forward in time to again show Pertti crossing a similar landscape, now as an alcoholic. The implication of this ellipsis is clear - the land around Pertti is entirely indifferent to where his life may lead him. A similar impression is created with Isto, a simpleton with money problems, who tries to reconnect with his ex-girlfriend. Despite his best intentions, Isto ends up in prison for paying with a counterfeit $€ 500$ bill, which, as mentioned above, he received when he pawned his television, and which Niko had forged and used at the same pawn shop to reclaim his 
stereo. ${ }^{18}$ When Isto is released, he finds his most prized possession, an American muscle car, vandalised under a bridge next to an infinite field of snow. Isto decides to steal a new vehicle for himself, but immediately gets stuck in a pile of snow. Howling in anger like a wild beast, he takes his rage out on the SUV, cursing and hitting the vehicle with his foot. The snow in both cases acts not only as a metaphor of the characters' entrapment, but as an actual physical barrier that blocks their already limited freedom.

In the used car dealership where Isto steals the car, Teuvo, a poor vacuum cleaner salesman, has to give up the car he lives in to pay his debts. When the car salesman (Samuli Edelmann) pressures him about when he will pay back his loans, Teuvo nervously says: 'When the snow melts'. While there is not any argumentative logic to his claim, it does follow an inherent emotional logic for anyone living in either Finland or Estonia, as it is a common hope that things will get better after the long dark winter. Another significant scene in Frozen Land that takes place outdoors is Antti spreading his late wife's ashes in a harbour area covered with nothing but snow as far as the eye can see. Antti later takes Tuomas, a man he holds responsible for the death of his wife, to the same place to kill him, although Tuomas had already been punished for the accident and has come to apologise. Indicating a significant connection between the frozen landscape and the characters' actions, the intertitle that marks the culmination of the film is named 'Snowpile' and highlights the upcoming snowballing effect, whereby all the different character-actions are going to pile on top of one another.

These examples should suffice to propose that the northern setting of these

18 The use of an element to connect the different lead characters is a highly common feature in multiprotagonist film. Similar to Frozen Land, a bill connects the different characters in L'argent and Twenty Bucks, while a rifle connects the global characters in Babel, which is itself a reference to Winchester'73 (Anthony Mann, USA, 1950). This device is also not uncommon in films that have a more arthouse inclination, as Autumn Ball makes similar use of the Pessoa's quote, and the donkey in Au hasard Balthazar (Robert Bresson, France/Sweden, 1966) connects its different characters. films does not merely serve as a decorative backdrop for the action, but has a direct effect on the characters' behaviour. I am not arguing that this attention to the northern cityscape and its severe effect on the characters' actions is somehow specific to multiprotagonist film, because there are single-, paired-protagonist and ensemble films that present similar concerns. Nevertheless, it is important to note that by connecting strangers via accidental encounters, arguably it is only the multi-protagonist form that can rise above an individual, couple or a specific group such as a family, proposing that the effects of the cold and dark environment extend beyond the particular FinnoUgric characters. The way the landscape is depicted in Frozen Land and Autumn Ball and the fact that a number of key scenes take place at night could be recognised as expressions of kaamos - an anguish caused by long dark winters. It is a state of mind that is similar to piblokto (or pibloktoq), also known as Arctic hysteria, which is caused by a lack of sun and great spatial isolation (both Finland and Estonia are among the least tensely populated countries in Europe). The mental conditions are generally described, similarly to the film's character-actions, as consisting of bursts of extreme excitement, followed by severe melancholy and mournfulness. In this light, alcoholism, among other social vices that critics have repeatedly noted in both films, is less the cause of the characters' chaotic behaviour, than a sign of a failed attempt to solve a deeper problem originating from the nearly inhabitable landscape. This appears to be supported by the ease with which a number of the characters in both films consider suicide as a solution to their problems (both countries have higher than average suicide rates compared to other European countries). The hostile northern land leads the characters to seek solutions to their emotional problems in desperate searches for love, and in alcohol and drugs. The futility of attempting to cure a condition which originates from geography is something that also appears to be evident to the characters leading them to destruction and (self-)harm. 


\section{CONCLUSION}

The extensive academic discussion on multi-protagonist/network narrative film has identified several features that are consistent to the form - interest in the social aspect of life, a strong focus on contemporary urban environment, and the depiction of accidental connections between (and their effect on) the characters. In this article I have shown how these characteristics are represented in films from small nations - in this case, Finland and Estonia as exemplified by Frozen Land and Autumn Ball. These films also depict the everyday lives of several interlinked characters, emphasise the importance of the cityscape in the lives of these characters, and connect their characters contingently, i.e. via random encounters. As in many other multi-protagonist films, the latter is accomplished through a traffic accident among other things. In addition to exploring the broader multi-protagonist aspects, these films also make use of some of the film form's lesser tropes - such as an element that travels from one character to the next, the form's tendency for selfreflexivity and its open interest in chaos theory, where a minor act is understood to have a larger unforeseen impact.

At the same time, I argue that the interest in the northern cityscape setting as expressed in Frozen Land and Autumn Ball is more regionally specific than is generally the case. Although most multi-protagonist films explore their cityscape setting with great care, and Los Angeles and New York, the most popular locations, are easily recognisable in the films, they also somewhat downplay their geographical specificity in order to make generalisations that can be applied more broadly than to just the specific city and thereby appeal to the widest possible audience.19 Instead, the North and East European examples discussed here make full use of their settings, which for foreigners, as a survey of the criticism shows,

As a typical example of the filmmakers' intent, Rodrigo Prieto, the cinematographer of $21 \mathrm{Grams}$, explains: 'We didn't want this to be "Memphis, Tennessee" where the story is happening, but any place in America - or in the world, even' (Prieto n.d.). appear distant and exotic. However, more than simply an exciting feature of the films, regionality can be seen as directly affecting the characters in these films. On the one hand, the cold, dark and isolated landscape is shown as wearing the characters down - a condition known as kaamos in these countries. The secluded dark landscape also acts as an ideal metaphor for the characters' introverted Finno-Ugric emotional state, a stereotype that both films support. On another level, the great barriers of snow not only act as a metaphor for entrapment, but are shown to literally debilitate people or thwart their plans of escape. At the same time, the constant darkness makes the characters extremely nervous or hysterically euphoric. On yet another level, the films resort to hyperbole and show that the secluded urban environments of Helsinki or Tallinn act as places where theft, assaults and even murder can take place in broad daylight. While these cinematic depictions do not necessarily reflect the everyday reality of these countries, the fictional Finno-Ugric characters of Frozen Land and Autumn Ball nonetheless provide a symbolic representation of a certain emotional tone of the life in these countries. While the global reception shows that foreigners see depressed characters and an excessively bleak environment in the films, the two are much more inherently connected than currently recognised. For the local audience this connection is often as logical as the feeling that things just have to get better when the snow finally melts.

\section{ACKNOWLEDGMENT}

I would like to thank the two anonymous reviewers of the article for their useful comments. 


\section{REFERENCES}

Ali, Lorraine 2015. 'Q\&A: Alejandro G. Iñárritu on Directing His Own Career'. - Los Angeles Times, 3 February. http://www.latimes.com/entertainment/ movies/moviesnow/la-et-mn-alejandro-gonzalezinarritu-retrospective-20150203-story.html (14 August 2017).

Anonymous 2009. 'SIFF 09: Review of Beautiful Estonian Drama Sügisball'. - Quiet Earth, 23 June. http://www.quietearth.us/articles/2009/06/22/

SIFF-09-Review-of-beautiful-Estonian-drama-Sgisball (14 August 2017).

Aronson, Linda n.d. 'The Six Sorts of Parallel Narrative'. - Linda Aronson. http://www.lindaaronson.com/ six-types-of-parallel-narrative.html (14 August 2017). Azcona, Maria del Mar 2005. 'Making Sense of a Multi-Protagonist Film: Audience Response Research and Robert Altman's Short Cuts (1993)'. - Miscelánea: A Journal of English and American Studies 32,11-22. Azcona, Maria del Mar 2008. 'Love Is a Many-Person'd Thing: Multi-Protagonist Tales of Contemporary Desire'. - Bells: Barcelona English Language and Literature Studies 17, 1-13.

Azcona, Maria del Mar 2010. The Multi-Protagonist Film. Malden, Oxford, Chichester: Wiley-Blackwell. Beal, Wesley 2009. 'Theorising Connectivity: The Form and Ideology of the Network Narrative.' - Jonathan Glynne, Fiona Hackney, Viv Minton (eds.), Networks of Design: Proceedings of the 2008 Annual International Conference of the Design History Society (UK). Boca Raton: Universal-Publishers, 405-409.

Berg, Charles Ramirez 2006. 'A Taxonomy of Alternative Plots in Recent Films: Classifying the "Tarantino Effect"'. - Film Criticism 31, 2, 5-61.

Bordwell, David 2006. The Way Hollywood Tells It: Story and Style in Modern Movies. Berkley, Los Angeles, London: University of California Press.

Bordwell, David 2008. Poetics of Cinema. New York, London: Routledge.

Bordwell, David; Staiger, Janet; Thompson, Kristin 2005. The Classical Hollywood Cinema: Film Style and Mode of Production to 1960. New York, London: Routledge.

Branigan, Edward 2002. 'Nearly True: Forking Paths, Forking Interpretations. A Response to David Bordwell's "Film Futures"'. - SubStance 97, 105-114.

Buckland, Warren 2009. 'Introduction: Puzzle Plots'. Warren Buckland (ed.), Puzzle Films: Complex Storytelling in Contemporary Cinema. New Jersey: Wiley-Blackwell, 1-12.

Cameron, Allan 2006. 'Contingency, Order, and the Modular Narrative: 21 Grams and Irreversible'. The Velvet Light Trap 58, Fall, 65-78.

Carmago, Sandy 2002."'Mind the Gap": The MultiProtagonist Film Genre, Soap. - M/C Journal 5, 5. http://journal.media-culture.org.au/0210/Carmago.php (14 August 2017).

Ciafone, Amanda 2014. 'The Magical Neoliberalism of Network Films'. - International Journal of Communication 8, 2680-2704.

Dawson, Tom 2006. 'Frozen Land (Paha maa)

(2006)'. - BBC, 5 October. http://www.bbc.co.uk/ films/2006/10/10/frozen_land_2006_review.shtml (14 August 2017).

Deleyto, Celestino 2012. 'Film Genres at the Crossroads: What Genres and Films Do to Each Other'. Barry Keith Grant (ed.), Film Genre Reader IV. Austin: University of Texas Press, 218-236.

Deleyto, Celestino 2016. From Tinseltown to Bordertown: Los Angeles on Film. Detroit: Wayne State University Press.

Doane, Mary Ann 2002. The Emergence of Cinematic Time: Modernity, Contingency, the Archive. Cambridge, MA; London: Harvard University Press.
Eesti filmi arengusuunad 2012-2020. http://filmi.ee/ wordpress/wp-content/uploads/2015/05/EF_arengusuunad_2012-2020.pdf (21 August 2017).

Foster, Tyler 2010. 'Frozen Land aka Paha maa'. - DVD Talk, 4 August. http://www.dvdtalk.com/reviews/43627/ frozen-land/ (14 August 2017).

Fundin, Johan 2006. 'Frozen Land'. - 10K Bullets,

27 November. http://10kbullets.com/reviews/frozenland/ (14 August 2017).

Gronvall, Andrea n.d. 'Frozen Land'. - Chicago Reader. http://www.chicagoreader.com/chicago/frozen-land/ Film?oid=1049916 (15 August 2017).

Hjort, Mette 2005. Small Nation, Global Cinema: The New Danish Cinema. Minneapolis, London: University of Minnesota Press.

IMF 2017a. Report for Selected Countries and Subjects. http://www.imf.org/external/pubs/ft/weo/2017/01/ weodata/weorept.aspx?pr.x $=77 \&$ pr.y $=7 \&$ sy $=2017 \&$ ey $=$ $2020 \&$ scsm $=1 \& s s d=1 \&$ sort $=$ country $\& d s=. \& b r=1 \& c=1$ $72 \& s=N G D P D \% 2 C N G D P D P C \% 2 C P P P G D P \% 2 C P P P P C \&$ grp $=0 \& a=$ (21 August 2017)

IMF 2017b. Report for Selected Countries and Subjects. http://www.imf.org/external/pubs/ft/weo/2017/01/ weodata/weorept.aspx?pr.x $=87 \&$ pr.y $=9 \&$ sy $=2016 \&$ ey $=$ $2022 \& s c s m=1 \& s s d=1 \&$ sort $=$ country $\& d s=. \& b r=1 \& c=9$ $39 \& s=N G D P D \% 2 C N G D P D P C \% 2 C P P P G D P \% 2 C P P P P C \&$ grp $=0 \& a=$ (21 August 2017).

Kinder, Marsha 2002. 'Hot Spots, Avatars, and Narrative Fields Forever: Buñuel's Legacy for New Digital Media and Interactive Database Narrative'. - Film Quarterly $55,4,2-15$.

Lanthier, Joseph Jon 2009. 'Sügisball'. - Slant, 1 June. http://www.slantmagazine.com/film/review/sugisball (15 August 2017).

Lübecker, Nikolaj 2015. The Feel-Bad Film. Edinburgh: Edinburgh University Press.

Manovich, Lev 1999. 'Database as a Symbolic Form'. Millennium Film Journal 34, Fall. http://www.mfj-online. org/journalPages/MFJ34/Manovich_Database_FrameSet.html (15 August 2017).

Maude, George 2010. Aspects of the Governing of the Finns. New York: Peter Lang.

Megahey, Noel 2007. 'Frozen Land'. - The Digital Fix,

10 May. http://film.thedigitalfix.com/content/id/64821/ frozen-land.html (15 August 2017).

Melzer, André; Hasse, Sebastian; Jeskulke, Oliver; Schön, Inga; Herczeg, Michael 2004. 'The Interactive and Multi-Protagonist Film: A Hypermovie on DVD'. International Conference on Entertainment Computing, 193-203.

Murray, Angus Wolfe 2006. 'Frozen Land'. - Eye for Film, 12 October. http://www.eyeforfilm.co.uk/review/ frozen-land-film-review-by-angus-wolfe-murray (15 August 2017).

Näripea, Eva; Mazierska, Ewa 2016. 'Transcending "Cold Intimacies" in Veiko Õunpuu's Works'. Baltic Screen Media Review 4, 61-87.

Paloheimo, Martti; Rouhunkoski, Mauri; Rutanen, Mirja 1974. Avameelselt abielust. Trans. Heino Mikk. Tallinn: Valgus.

Parshall, Peter F. 2012. Altman and After: Multiple Narratives in Film. Lanham: The Scarecrow Press. Pessoa, Fernando 1998. The Tobacco Shop. Trans. Richard Zenith. New York: Grove Atlantic.

http://www.ronnowpoetry.com/contents/pessoa/ TobaccoShop.html (15 August 2017).

Prieto, Rodrigo n.d. 'Production Notes'. - 21 Grams. http://www.21-grams.com/content/prodnotesData.php (15 August 2017).

Quart, Alissa 2005. 'Networked'. - Film Comment 41, 4, 48-51.

Rich, Nathaniel 2009. 'Robert Altman's Short Cuts: Stop Comparing It to Nashville'. - Slate, 27 January. http://www.slate.com/articles/arts/dvdextras/2009/01/ robert_altmans_short_cuts.html (15 August 2017). 
Rizov, Vadim 2009. 'Autumn Ball Creeps through the Marginalia of Baltic Consciousness'. - The Village Voice, 3 June. http://www.villagevoice.com/film/autumnball-creeps-through-the-marginalia-of-balticconsciousness-6391199 (15 August 2017).

Silvey, Vivien 2009. 'Not Just Ensemble Films: Six Degrees, Webs, Multiplexity and the Rise of Network Narratives.' - Forum: University of Edinburgh Postgraduate Journal of Culture and the Arts 8, Spring. http://www.forumjournal.org/article/view/621/906 (15 August 2017).

Silvey, Vivien 2012. Network Films: A Global Genre? PhD thesis. Australian National University. Canberra. http://hdl.handle.net/1885/10535 (15 August 2017).

Simons, Jan 2008. 'Complex Narratives'. - New Review of Film and Television Studies 6, 2, 111-126.

Smith, Evan 1999/2000. 'Thread Structure: Rewriting the Hollywood Formula'. - Journal of Film and Video 51, 3/4, 88-96.

Smith, Greg M. 2005. 'Passersby and Politics: City of Hope and the Multiple Protagonist Film. - Diane Carson, Heidi Kenaga (eds.), Sayles Talk: New Perspectives on Independent Filmmaker John Sayles. Detroit: Wayne State University Press, 117-133.

Tabucchi, Antonio 1992. Dreams of Dreams and the Last Three Days of Fernando Pessoa. San Francisco: City Lights Books.

Tolstoy, Leo 2006. The Forged Coupon, and Other Stories. Trans. Charles Wright. http://www.gutenberg. org/files/243/243-0.txt (15 August 2017).

Tröhler, Margrit 2007. Offene Welten ohne Helden. Plurale Figurenkonstellationen im Film. Marburg: Schüren.

Tröhler, Margrit 2010. 'Multiple Protagonist Films: A Transcultural Everyday Practice.' - Jens Eder, Fotis Jannidis, Ralf Schneider (eds.), Characters in Fictiona Worlds: Understanding Imaginary Beings in Literature, Film, and Other Media. Berlin, New York: de Gruyter, 459-477.

Unt, Mati 1979. Sügisball. Stseenid linnaelust. Tallinn: Eesti Raamat. 